\title{
Play Based Scheme: Its effectiveness to Students' Performance in Learning Conversion/Substitution of Weights and Measures
}

\author{
Sheryl Ompoc ${ }^{1}$
}

\begin{abstract}
The purpose of this study is to determine the effectiveness of play based scheme to student's performance in learning conversion/substitution of weights and measures of the Grade 7 students of Danao National High School, School Year 2019-2020. Specifically, it also sought the student's attitude and perception in using play in learning conversion. This study used a descriptive survey method. The interview, actual performance and questionnaires were also utilized in gathering data. The analysis of the data consisted mainly of tabulations, percentages as well as computations of weighted mean. The respondents consisted of 64 grade 7 students from sections Hope and Love. The study yielded the following results; that from 52 students who did not reach the standard passing scores in pre-test, it lowers down to 7 students after the conduct of the post test. That 44 or 81.5 percent of the student's population has reached the passing standard score after the implementation of the Play Based scheme. The study also yielded that most of the students agrees that using the play based scheme is useful and effective in learning conversion/substitution of weights and measures. Finally, the play based scheme has attained its goal in providing and improving students skills in learning conversion / substitution of weights and measures. With these, it is suggested that teachers should make use of play as an innovative way of teaching specially challenging lessons since most of the grade 7 are playful in nature. School Heads may also support each teachers by supporting financially in their play based scheme method of teaching from the school's MOOE budget. Schools may also link to government agencies for greater implementation of the Play based scheme. Finally, the study may be replicated in a wider scope to confirm results of this study.
\end{abstract}

\section{Keywords: Play Based; substitution; conversion.}

\footnotetext{
${ }^{1}$ Teacher III, Department of Education, Danao National High School, Jasaan Misamis Oriental , Philippines. Email: sheryl.ompoc@deped.gov.ph
} 


\section{INTRODUCTION}

Teachers of today are encourage to use instructional materials daily in teaching and learning process for the reason that many researchers had found out that teaching and learning could be facilitated in an innovative way. Innovative teaching methods develops student's personal qualities - communicativeness, competence, oratorical ability and democracy. (Drahansky et al., 2016)

Today's education systems are required to be both effective and efficient, or in other words, to reach the goals set for them while making the best use of available resources.

(Serdyukov, 2017). Technology \& Livelihood Education develops the technological skills of every students to prepare them in future workforce. In fact this is one of the salient features in the development and implementation of K to 12 curriculum which started last 2015.

Measurements are key to baking/cooking. When baking, an incorrect measurement can ruin your product. For the past several years of teaching Technology \& Livelihood Education, it has been observed that students find it difficult to cope with lessons pertaining to numeracy. Of the current school year, out of 64 students in Grade 7 level comprising of two sections, only 10 of them shows enthusiasm working on numbers, hence be able to participate and got passing scores in during pre-test.

Table 1 presents the mean percentage scores during the conduct of the pre-test. The conducted Pretest revealed that the men percentage score of section love is only $45 \%$ while section hope rated slightly higher with $57 \%$. Though the latter showed higher mean percentage score it is still considered far beyond the required standard of Mean percentage of at least $75 \%$. If 2 sections are to be combined, $52 \%$ is still far from the target standard rate.

\section{Table 1. Mean Percentage of the conduced pre-test.}

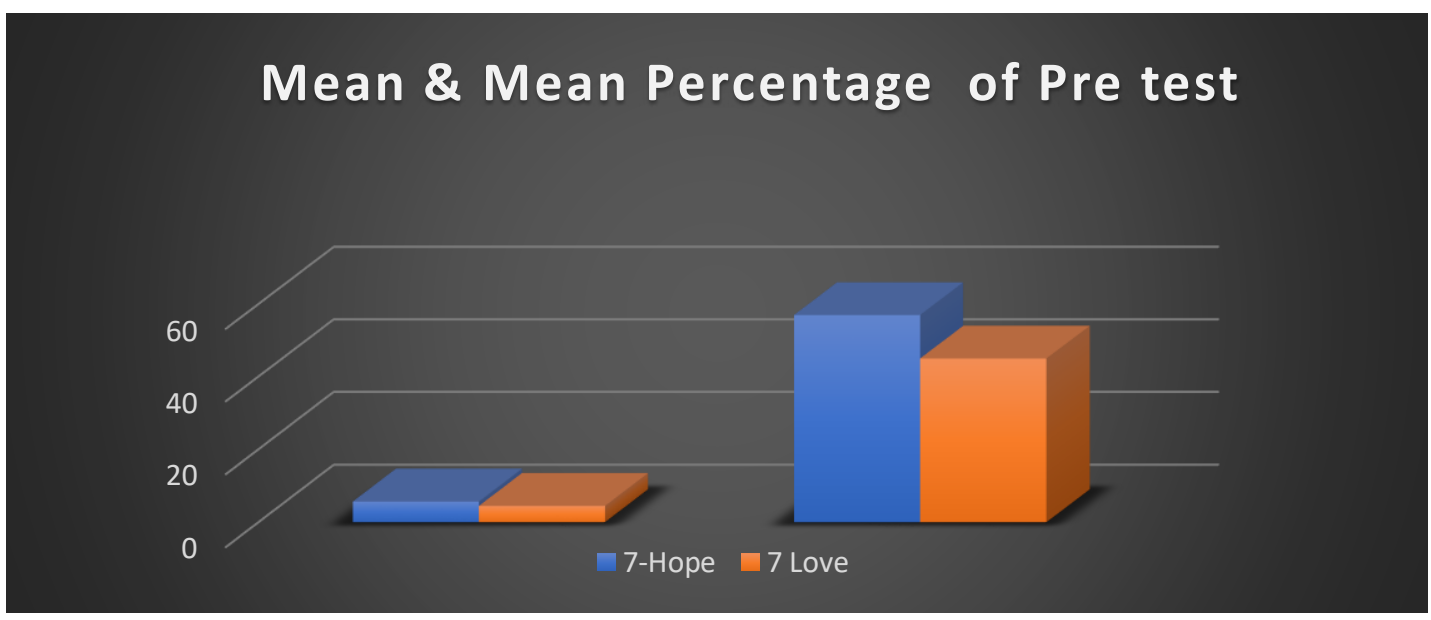

Moreover student's tend to decline to work on activities be it individual or group knowing that numbers are incorporated on such activities. Out of 11 covered competencies, the competency pertaining to conversion/ substitution of weights and measures is the most challenging topics to be discussed since many of the students finds it hard to develop this skill. This is clearly manifested through the recorded quizzes and exam results of the learners. 


\section{Table 2. Mean percentage score of the total competencies covered.}

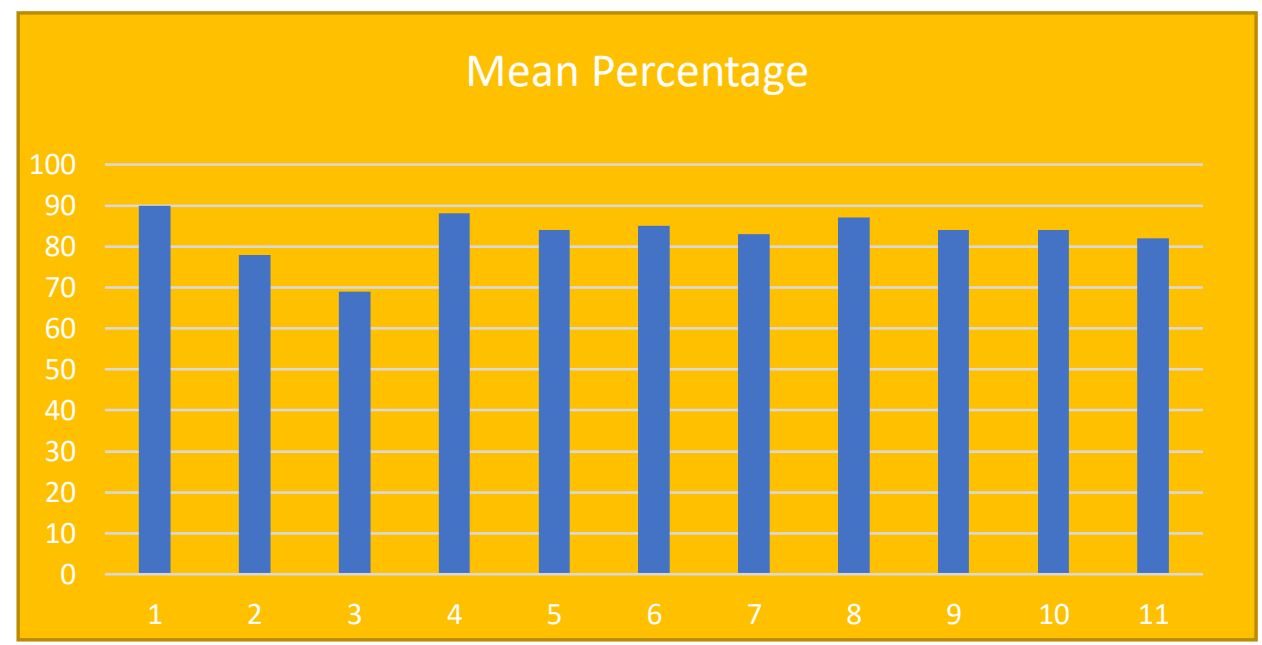

Furthermore, upon further inquiry of the researcher the mathematics teacher also shared the same dilemma as she also confirmed that these students really are troubled with in comes to numbers while some of them struggles to do even simple mathematical operations.

This action research responds and adheres to call of the Department of Education to develop and produce literate $21^{\text {st }}$ century learners. In the Danao National High School all teachers have created and used varied instructional materials be it printed or non-printed to makes learnings the easier way. In fact all of them has LRMDS portal account that is use to access downloadable printed instructional materials easily. But due to problems pertaining to network availability, teachers has difficulty accessing the said sites and opted to find alternative ways to make learning not just easy but fun as well. Making innovative ways of teaching has been one of the main goals of teachers nowadays. It enhances the memory level of the learners. At this time, that education has spread wide and entirely, oral teaching cannot be the key to successful pedagogy; therefore the teachers has to make teaching and learning process interesting and fun yet educative on the side of the learners..

\section{Innovation, Intervention and strategy.}

To help aid in the difficulties of the students pertaining to conversion/ substitution of weights and measures, the researcher tried to talk and observe the students on the possible remedies to solve the plight. It has been observed that grade 7 learners, as young as they are more playful. This gives the researcher an idea of making the teaching fun yet produces comprehensive learning to all grade 7.In order to deliver and teach this particular topic, the researcher incorporates a play called "MATH IN THE KITCHEN" where students are grouped in to three and are exposed to the different tools and utensil in the kitchen particularly those that are considered measuring tools for them to manipulate. They were also provided with colored sand, clay and water assuming this as the ingredients in baking activity.

Since these competency are to be tackled in four days, students are first introduce to the measuring tools that they will be using on the first day. They get to examine and hold and play a little with these tools for them to feel comfortable using such tools. Also, a pre-test is given to them to evaluate student's level of understanding in conversion/substitution of weights and measures. On the second day they were thought how to manipulate properly the tools, they were also taught as to the proper way of using such tools so as to arrive with accurate measurements. They were also 
informed as to what kind of ingredients are to be measured on a particular tool. On the third day. Learners are grouped into three where an activity awaits for them. 3 stations providing activities/ play are prepared. To make the environment more realistic to play, the lesson was held in the kitchen/TLE laboratory were they get to see actual \& real ingredients in baking \& cooking. The emphasis of having a play on that day through informing the kids is done so as not to distort their excitement to play. As the group finishes 1 play they are to visit next station. These will continue until all of them have visited and completed the assigned plays in each station. With the close supervision of the teacher. All students must have manipulated the tools and be able to use it in a play manner. On the fourth day is an actual one on one activity where a rubrics in giving points or grade is used and on the fifth day, a post test is conducted as well as the administration of the survey pertaining to the learner's perception on the conduct of play.

\section{ACTION RESEARCH QUESTIONS}

\section{This research will seek to find answers on the following questions:}

1. Does play based scheme improves student's knowledge in learning Conversion//substitution of weights and measures?

2. Does play based scheme promotes students skills in learning conversion//substitution of weights and measures?

3. What is the attitude level of the learners in using play in learning conversion/substitution of weights and measures?

4. What is the Learner's level of effectiveness in using play based scheme In learning conversion/substitution of weights and measures?

5. What is the Learner's perception in using the play based scheme in learning conversion/substitution of weights and measures?

\section{Action Research Methods}

\section{A. Participants}

Participants to this study are the learners comprising the 2 sections of Grade 7 level of Danao National High School namely Hope \& Love. 34 males and 30 females a total of 64 grade 7 learners. Records showing low scores in their pre-test were used as the bases for the conduct of this research.

\section{Table 3. Number of Students per sections}

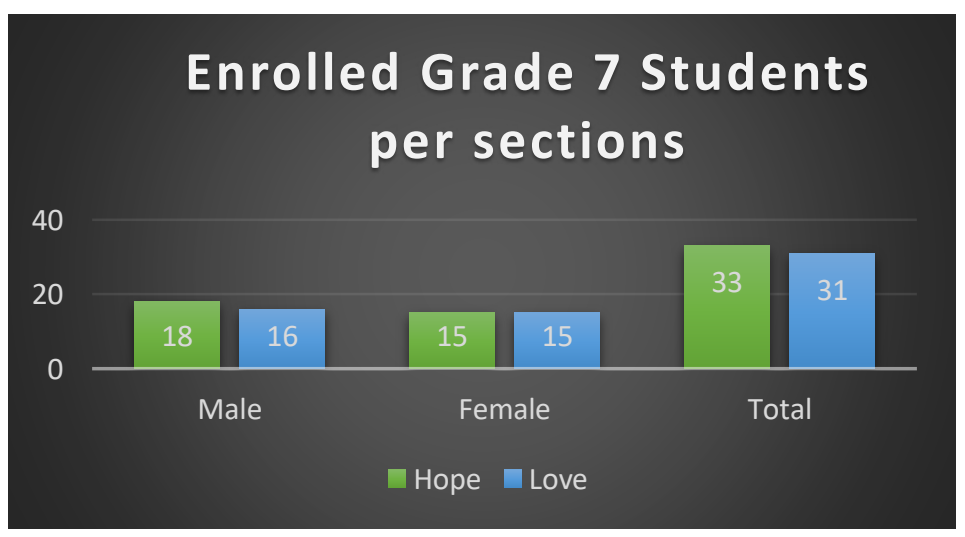




\section{A. Data Gathering Methods}

Permission from proper authorities will be secured before the commencement of the data gathering procedure. The participants will be informed of the intention of the study, and how the data will be gathered, used, and stored. They will also be informed of: who can access the information they have given; their right to refuse to answer any question that they feel uncomfortable with; and their right to request of the results of the study. The survey questionnaire will be administered personally by the teacher/researcher.

The research instruments are the teacher researcher's made questionnaires and the Pre-post test indicated in the TLE learners module is conducted. For the actual assessment/performance toys like measuring cups, spoons, weighing scale and smart scale or digital scale are used. Likewise, water will be used to assume the liquid ingredients in baking/cooking while ordinary sand, colored sand and clays are used to assume the dry ingredients in baking/cooking. Actual performance or demonstration with rubrics are also used to determine student's skills in learnings and finally the Post test to determine student's acquired knowledge . Rubrics for performance evaluation is presented and discussed to the students prior to its utilization. The survey questionnaires are answered by the students while translation is done if necessary for their better understanding.

The research also strictly observed the ethics of the research. An unstructured interview is done to validate the student's responses of the questionnaire. The research used statistical tool such as frequency, percentage, mean and standard deviation in calculating and interpreting the data. The researcher interpreted and presented results for conclusions and recommendations

\section{DISCUSSION OF RESULTS AND REFELCTION}

The researcher purchased and used toys that serves a tool of the students for learning conversion /substitution of weights and measures. One of the unique characteristics of grade 7 students is being playful. Although, enrolled in secondary and often regarded as adolescents, grade 7 students seems to have difficulty detaching from their childhood activities like play. For the teacher, this also served as her instructional material for teaching conversion and/substitution of weights and measures. This innovative idea aims to helped the pupils to lean conversion /substitution of weights \& measures in enjoyable and fun yet educative on their part. The strategy did not only help students to improve their skills in conversion and/substitution of weights and measures but this also strengthens the camaraderie between students and teachers as well. Table 4 below presents the number of learners who did not reach the standard passing score before and after employing the Play Based Scheme. The conducted Pre-test is a 10 items test. It can be gleaned from the table that only 12 students got a passing score during pre-test. The 52 or 82.5 haven't reached the required passing score.

Table 4. Frequency \& Percentage of students who did not reach the standard passing score before and after employing the Play Based Scheme.

Frequency of learners who
Did not reach standard
passing score $(75 \%)$

\begin{tabular}{lll}
\hline Pre-Test & 52 & $82.5 \%$ \\
Post Test & 7 & $11.2 \%$ \\
\hline
\end{tabular}

Furthermore, the table also presents that after employing the play based scheme the number of students who did not reached the required passing score was lessen into 7 or $11.2 \%$. This seven 
students therefore still needs to be reinforced with effective learning strategy in order to improve their skills in conversion / substitution of weights and measures.

Moreover, this implies that the play based scheme conducted by the teacher and the students helped the students improve their conversion skills. Based on the data 57 students were able to improve their knowledge in conversion and substitution of weights and measures. While it's true that there are still 7 who still needs intensive remediation using another strategy that suits their ability and needs. There might be another hindering factor for these remaining children that the researcher should look after such as absenteeism, and lack of parental support .

Table 5 presents the frequency of scores of the students during the actual assessment/performance evaluated with a presented, discussed and agreed rubrics between the students and the teacher. Using the rubrics, highest possible score is 15 while 3 is the lowest possible score.

Table 5. Frequency of Student's Scores during actual assessment/performance.

\begin{tabular}{llc}
\hline Scores & Frequency & \multicolumn{2}{c}{ Percent } \\
\hline 6 & 1 & 1.9 \\
9 & 4 & 7.4 \\
10 & 5 & 9.3 \\
11 & 10 & 18.5 \\
12 & 10 & 18.5 \\
13 & 9 & 16.7 \\
14 & 3 & 5.6 \\
15 & 12 & 22.2 \\
\hline Passing Score & & \\
\hline
\end{tabular}

Table shows that 44 or $81.5 \%$ of the students have reached the required standard passing score of $75 \%$. This further implies that students have actually developed their skills in conversion/substitution of weights and measures using the play based scheme. This might be attributed by the fact that actual experience of toys in learning helped the students understand more the lessons. Play is the mechanism by which children learn - how they experience their world, practice new skills, and internalize new ideas - and is therefore the development and the role of play, teachers can intentionally select toys to meet young children's unique needs and interests, supporting learning. years supervisory experience and five years as an early intervention specialist. (Importance, Interview, \& Paley, 2009)

Hence, table 6 shows the overall mean of the students during the conduct of the actual assessment/performance. It can be gleaned from the table that the mean scores of the students surpasses the required passing score which is 11 . Indeed the play based scheme has helped them understand the concept of conversion/substitution of weights and measures.

Table 6. Total Mean Score of the Actual Assessment Using the Play Based Scheme

Mean SD

\begin{tabular}{lcc}
\hline Actual Performance & 12.24 & 2.074 \\
With Rubrics & & \\
\hline
\end{tabular}


Table 7 below presents the attitude of the students in learning conversion /substitution of weights and measures. Table reveals that play in fact helped them understand easily the concept/lesson presented by the teacher especially in learning conversion/substitution of weights $\&$ measure. The consensus of the students also agrees strongly that play is both a useful instructional material and makes them experience things actively. Moreover they also strongly agrees to the idea that play can offer better learning opportunities for them and makes their learning more meaningful and effective.

Table 7. Attitude Level of the students/learners using play in learning conversion/substitution of weights and measures

\begin{tabular}{|c|c|c|c|}
\hline Statements & Mean & SD & Qualitative Description \\
\hline $\begin{array}{l}\text { 1. Play is very useful for } \\
\text { instructional purposes. }\end{array}$ & 3.71 & .458 & Strongly Agree \\
\hline $\begin{array}{l}\text { 2. Play used to help you as } \\
\text { learners understand } \\
\text { easily the concept/lesson } \\
\text { presented by the teacher } \\
\text { especially in learning } \\
\text { conversion/substitution } \\
\text { of weights \& measure. }\end{array}$ & 3.69 & .488 & Strongly Agree \\
\hline $\begin{array}{l}\text { 3. Play can offer better learning } \\
\text { opportunities }\end{array}$ & 3.58 & .495 & Strongly Agree \\
\hline $\begin{array}{l}\text { 4. Play method makes learning } \\
\text { more meaningful } \\
\text { \& effective }\end{array}$ & 3.58 & .499 & Strongly Agree \\
\hline $\begin{array}{l}\text { 5. Play method helps me to } \\
\text { experience things actively }\end{array}$ & 3.71 & .458 & Strongly Agree \\
\hline
\end{tabular}

Adults respond so negatively to play because they denote it as simply having fun and, therefore, as a waste of time. But though play can be fun, as one of the three essential drives - love, play, workit contributes to the best kind of learning. Play operates as more than a creative urge; it also functions as a fundamental mode of learning. This was further reinforce by a study of a teacher to the group of students in a children school at Tuffs University near Boston, who offers a straightforward testimony how play drives the teacher and students to work together and create a positive learning experience. Given with a numerous pictures of a heart that learners usually associates with valentines day, learners become fascinated of this basic human organ. Using their interest and curiosity, the teacher made them take their own pulse. Because learners were interested in the topic and activity, the kids considered themselves to be playing with hearts. But such play led them open to "working" on their skills of measurement, and vocabulary. (Irvine,2001)

Table 8 presents the learners level of effectiveness in using the play based scheme. Consensus of the students agrees that they were able to do conversion/substitution with the used of play based scheme. 
Table 8. Learner's level of effectiveness in using play based scheme

\begin{tabular}{llll}
\hline Statements & Mean & SD & Qual. Description \\
\hline 1. I was able to do conversion/ \\
$\begin{array}{l}\text { substitution } \\
\text { of weights using the } \\
\text { play based scheme }\end{array}$ & 3.67 & .477 & Strongly Agree \\
2. $\begin{array}{l}\text { Play based scheme help me } \\
\text { a lot in understanding } \\
\text { conversion/substitution } \\
\text { of weights \& measure. }\end{array}$ & 3.51 & .506 & Strongly Agree \\
3. $\begin{array}{l}\text { The play based scheme } \\
\text { serves as my partner in } \\
\text { understanding \& doing } \\
\text { conversion/substitution } \\
\text { of weights \& measure }\end{array}$ & 3.58 & .499 & Strongly Agree \\
4sing the Play based scheme, & 3.71 & .458 & Strongly Agree \\
$\begin{array}{l}\text { I was able to do } \\
\text { simple mathematical operations }\end{array}$ & & & \\
\hline
\end{tabular}

Legend : Strongly Disagree1.00 - 1.75; Disagree1.76 - 2.5; Agree2.51 - 3.25 Strongly Agree3.26 $-4.00$

Play is intrinsically motivated and leads to active engagement and joyful discovery. It also provides a singular opportunity to build the executive functioning that underlies adaptive behaviors at home; improve language and math skills in school; build the safe, stable, and nurturing relationships that buffer against toxic stress; and build social- emotional resilience.(Yogman et al., 2018)

Table 9 presents the student's perception with the use of the play based scheme. Table reveals that on the average, the students strongly agree that the play based scheme makes them develop their interest in learning conversion / substitution of weights and measures. With the play based scheme, they can now do simple mathematical operations with less supervision.

Table 9. Learner's Perception in Using the Play Based Scheme.

\begin{tabular}{|c|c|c|c|}
\hline Statements & \multirow[t]{2}{*}{ Mean } & \multirow[b]{2}{*}{.505} & \multirow{2}{*}{$\begin{array}{l}\text { Qualitative } \\
\text { Description } \\
\text { Strongly Agree }\end{array}$} \\
\hline $\begin{array}{l}\text { 1. The Play Based scheme makes } \\
\text { me develop my } \\
\text { interest in learning conversion/ } \\
\text { substitution of } \\
\text { weights \& measure. }\end{array}$ & & & \\
\hline $\begin{array}{l}\text { 2. With the Play Based Scheme, } \\
\text { I can now do } \\
\text { simple mathematical operations } \\
\text { with less } \\
\text { supervision }\end{array}$ & 3.38 & .535 & Strongly Agree \\
\hline $\begin{array}{l}\text { 3. The play based scheme is very } \\
\text { helpful since } \\
\text { I can now have more time to pra } \\
\text { conversion / substitution of weigh }\end{array}$ & 3.67 & .522 & Strongly Agree \\
\hline
\end{tabular}


and measure

using my toys available at home.

4. Using the Play based scheme, I can

Strongly Agree

easily

remember the process of conversion/

substitution

of weights and measure

5. The play based scheme is useful

in developing

my skill in conversion/ substitution of weights and measure

Using the Play based scheme, they can now have more time to practice conversion / substitution of weights using their own toys available at home. The above responses all got almost equal means which is also the highest mean of 3.67 (strongly Agree) with the standard deviation of .522. The responses that got the lowest mean is "the play based scheme enables them to do simple mathematical operations" with a mean of 3.38 and a standard deviation of .535. This may be because of the fact that some of the students in the grade 7 still is struggling and tries hard on learning simple math operations. Some of them even has math anxiety. Moreover to confirm the researchers observation, an inquiry was made with the mathematics teacher which also has the same problem with the math anxieties felt by her students, characterized by sleeping in her class, avoidance behavior, refusal to collaborate with others and failure to share his/her ideas in class.

\section{CONCLUSION}

The researcher conclude therefore that play based scheme has helped the students a lot in improving their learning in conversion/substitution of weights and measures. Play Based scheme therefore has been found to be effective in the delivery of instruction particularly in leaning conversion. It also increases students-teachers friendship/companionship in order to make every child a good learner.

\section{RECOMMENDATION} proposed:

Based on the findings and conclusions, the following recommendations are hereby

1. A play based scheme should be used as strategy to grade 7 learners especially to those concepts/lessons that children has hard time to understand.

2. Teachers should think/ implement various kinds of play so as not to become monotonous on the part of the students.

3. School Heads should support the teachers in providing the needs of the teacher especially in the conduct of play based activities to be funded by school MOOE.

4. The district supervisor and school heads may monitor the use of the play based activities.

5. This study should also be presented among parents so they will understand that play in not just merely for children's leisure but could also a good avenue to learn.

6. For a more holistic and effective implementation of this, Play based activities can be more effective if it strengthens its cooperation and fosters greater partnership with the Local Government units and other department of the government. 
Action Plan

\begin{tabular}{|c|c|c|c|c|c|}
\hline Objectives & $\begin{array}{l}\text { Time } \\
\text { Fram } \\
\text { e }\end{array}$ & Activity & $\begin{array}{l}\text { Persons } \\
\text { Involved }\end{array}$ & $\begin{array}{l}\text { Fund } \\
\text { Needed }\end{array}$ & Expected Output \\
\hline $\begin{array}{l}\text { Prepare action } \\
\text { research } \\
\text { proposal }\end{array}$ & $\begin{array}{l}\text { June } \\
2019\end{array}$ & $\begin{array}{l}\text { Conceptualizing } \\
\text { the research } \\
\text { proposal }\end{array}$ & $\begin{array}{l}\text { Teacher } \\
\text { Researcher }\end{array}$ & none & $\begin{array}{l}\text { Formulated the Action } \\
\text { Research }\end{array}$ \\
\hline $\begin{array}{l}\text { Conduct } \\
\text { conference to } \\
\text { school head } \\
\text { about the } \\
\text { implementation } \\
\text { of the project }\end{array}$ & $\begin{array}{l}\text { June } \\
2019\end{array}$ & $\begin{array}{l}\text { Conference with } \\
\text { the school head }\end{array}$ & $\begin{array}{l}\text { School Head } \\
\text { \& Teacher } \\
\text { Researcher }\end{array}$ & none & $\begin{array}{l}\text { Conducted conference } \\
\text { with the head }\end{array}$ \\
\hline Conduct Pre-test & $\begin{array}{l}\text { June } \\
2019\end{array}$ & $\begin{array}{l}\text { Pre-test in } \\
\text { conversion/substi } \\
\text { tution of weights } \\
\& \text { measures }\end{array}$ & $\begin{array}{l}\text { Teacher } \\
\text { researcher \& } \\
\text { Grade } 7 \\
\text { Students } \\
\end{array}$ & none & Result of the pre-test \\
\hline $\begin{array}{l}\text { Designing and } \\
\text { purchasing of } \\
\text { toys }\end{array}$ & $\begin{array}{l}\text { Augus } \\
\text { t } 2019\end{array}$ & $\begin{array}{l}\text { Teacher/research } \\
\text { er design and } \\
\text { select } \\
\text { appropriate tools } \\
\text { to use }\end{array}$ & $\begin{array}{l}\text { Teacher } \\
\text { Researcher }\end{array}$ & $\begin{array}{l}\text { Pls } \\
\text {.refer } \\
\text { to the } \\
\text { cost } \\
\text { estimat } \\
\text { es }\end{array}$ & $\begin{array}{l}\text { Designed and purchased } \\
\text { appropriate toys }\end{array}$ \\
\hline $\begin{array}{l}\text { Implementation } \\
\text { of the Project }\end{array}$ & $\begin{array}{l}\text { Augus } \\
\text { t } \\
2019\end{array}$ & $\begin{array}{l}\text { Teacher } \\
\text { researcher } \\
\text { conducted the } \\
\text { play based } \\
\text { scheme in the } \\
\text { delivery of } \\
\text { instruction }\end{array}$ & $\begin{array}{l}\text { Teacher } \\
\text { Researcher \& } \\
\text { Grade } 7 \\
\text { Students }\end{array}$ & none & $\begin{array}{l}\text { Conducted the Play } \\
\text { Based Scheme }\end{array}$ \\
\hline $\begin{array}{l}\text { Gathering the } \\
\text { survey } \\
\text { Questionnaire }\end{array}$ & $\begin{array}{l}\text { Septe } \\
\text { mber } \\
2019\end{array}$ & $\begin{array}{l}\text { Collect the } \\
\text { questionnaires }\end{array}$ & $\begin{array}{l}\text { Teacher } \\
\text { Researcher \& } \\
\text { Grade } 7 \\
\text { Students } \\
\end{array}$ & none & $\begin{array}{l}\text { Retrieved the survey } \\
\text { questionnaires }\end{array}$ \\
\hline $\begin{array}{l}\text { Conducting the } \\
\text { Post Test }\end{array}$ & $\begin{array}{l}\text { Septe } \\
\text { mber } \\
2019 r\end{array}$ & $\begin{array}{l}\text { Posttest is given } \\
\text { to students }\end{array}$ & $\begin{array}{l}\text { Teacher } \\
\text { Researcher \& } \\
\text { Grade } 7 \\
\text { Students }\end{array}$ & none & $\begin{array}{l}\text { Result of the conducted } \\
\text { Post Test }\end{array}$ \\
\hline $\begin{array}{l}\text { Analyzing \& } \\
\text { Interpreting the } \\
\text { result }\end{array}$ & $\begin{array}{l}\text { Octob } \\
\text { er, } \\
2019\end{array}$ & $\begin{array}{l}\text { Teacher } \\
\text { researcher } \\
\text { analyzed data } \\
\text { and result }\end{array}$ & $\begin{array}{l}\text { Teacher } \\
\text { Researcher }\end{array}$ & none & Analyzed Result \\
\hline $\begin{array}{l}\text { Creation of Final } \\
\text { report }\end{array}$ & $\begin{array}{l}\text { Octob } \\
\text { er, } \\
2019\end{array}$ & $\begin{array}{l}\text { Teacher } \\
\text { researcher makes } \\
\text { the final report }\end{array}$ & $\begin{array}{l}\text { Teacher } \\
\text { Researcher }\end{array}$ & none & Submitted Final Report \\
\hline
\end{tabular}




\begin{tabular}{|l|l|l|l|l|l|}
\hline $\begin{array}{l}\text { Submission of } \\
\text { Final Report }\end{array}$ & $\begin{array}{l}\text { Octob } \\
\text { er } \\
2019\end{array}$ & $\begin{array}{l}\text { Teacher } \\
\text { researcher } \\
\text { submits the final } \\
\text { report to the } \\
\text { office }\end{array}$ & $\begin{array}{l}\text { Teacher } \\
\text { Researcher }\end{array}$ & none & \\
\hline
\end{tabular}

\section{COST ESTIMTES}

\begin{tabular}{|l|l|l|l|}
\hline \multicolumn{1}{|c|}{ Materials } & \multicolumn{1}{c|}{ Cost Estimate } & \multicolumn{1}{c|}{ Fund } & \multicolumn{1}{c|}{ Persons Involved } \\
\hline 1 ream Bond Paper & 250.00 & MOOE & $\begin{array}{l}\text { Researcher, School } \\
\text { Head }\end{array}$ \\
\hline Toys & $\mathbf{3 0 0 . 0 0}$ & PTA & $\begin{array}{l}\text { Researcher, School } \\
\text { Head. PTA Org. }\end{array}$ \\
\hline Binding Fee & $\mathbf{5 0 . 0 0}$ & MOOE & $\begin{array}{l}\text { Researcher, School } \\
\text { Head }\end{array}$ \\
\hline
\end{tabular}




\section{REFERENCES}

Drahansky, M., Paridah, M. ., Moradbak, A., Mohamed, A. ., Owolabi, F. abdulwahab taiwo, Asniza, M., \& Abdul Khalid, S. H. . (2016). We are IntechOpen, the world 's leading publisher of Open Access books Built by scientists, for scientists TOP $1 \%$. Intech, i(tourism), 13. https://doi.org/http://dx.doi.org/10.5772/57353

Importance, T., Interview, P. A., \& Paley, V. G. (2009). The Importance of Fantasy, Fairness, and Friendship in Children's Play An Interview with Vivian Gussin Paley. The American Journal of Play, 2(2), 122-138.

Irvine, L. (2001). The power of play. Anthrozoos, 14(3), 151-160. https://doi.org/10.2752/089279301786999454

Serdyukov, P. (2017). Innovation in education: what works, what doesn't, and what to do about it? Journal of Research in Innovative Teaching \& Learning, 10(1), 4-33. https://doi.org/10.1108/jrit-10-2016-0007

Yogman, M., Garner, A., Hutchinson, J., Hirsh-Pasek, K., Golinkoff, R. M., Baum, R., ... Wissow, L. (2018). The power of play: A pediatric role in enhancing development in young children. Pediatrics, 142(3). https://doi.org/10.1542/peds.2018-2058 